\title{
ПЕРСОНАЛІЗАЦІЯ В ОНКОЛОГІЇ: ІНДИВІДУАЛЬНИЙ ПІДХІД ДО ПРОФІЛАКТИКИ ТРОМБОЕМБОЛІЧНИХ УСКЛАДНЕНЬ ПРИ ПАНГІСТЕРЕКТОМIї
}

\author{
${ }^{1}$ ДВНЗ «Тернопільський державний медичний університет \\ імені І. Я. Горбачевського МОЗ України», м. Тернопіль, Україна \\ ${ }^{2}$ Тернопільський обласний клінічний онкологічний диспансер, м. Тернопіль, Україна
}

\begin{abstract}
Мета: підвищити ефрективність хірургічного лікування хворих на рак ендометрія шляхом оптимізації діагностичної тактики та хірургічної профрілактики тромботичних ускладнень у ранній післяопераційний період.

Матеріали і методи. Обстежено 3 групи жінок: I - група 30 соматично здорових жінок; II - контрольна група (група порівняння) - ретроспективно проаналізовано 120 карт стаціонарних хворих на рак ендометрія, яким виконано пангістеректомію в період 2010-2013 рр.; III - основна група жінок, хворих на рак ендометрія, яким виконували хірургічне втручання (пангістеректомію) - 147 хворих, які перебували на хірургічному лікуванні в 2014-2017 рр.

Результати. На першому етапі нашого дослідження проаналізовано основні антропометричні характеристики обстежених жінок і ризик виникнення тромботичних ускладнень за шкалою J. Caprini. В основній групі обстежених і в групі порівняння виявлено зростання ризику виникнення тромбоемболій порівняно з групою здорових осіб, що вказувало на високий і вкрай високий ризик їх виникнення на операційному етапі лікування.

При вивченні гемостазіологічних показників в основній групі та групі порівняння у доопераційний, інтраопераційний і ранній післяопераційний періоди виявлено гіперкоагуляцію з ознаками внутрішньосудинного згортання, що проявлялась достовірним зниженням протромбінового індексу та скороченням ТЧ і АЧТЧ з одночасним підвищенням рівня ПЧ, ФГ, D-димеру. Ознаки гіперкоагуляції зростали під час операції та на 1-5 добу післяопераційного періоду і поступово знижувались до доопераційних значень, за винятком D-димеру, пік якого спостерігали на 8 добу післяопераційного періоду.

Створено і впроваджено в практику охорони здоров'я алгоритм оптимізації діагностичної та хірургічної профрілактики тромбоемболій у хворих на рак ендометрія з врахуванням ризику їх виникнення.

Висновки. 1. Досягнуто зниження смертності в ранній післяопераційний період у хворих на рак ендометрія від тромбоемболії легеневої артерії з 4,17 до 0 \% і післяопераційних тромботичних ускладнень - 3 11,67 до 1,36 \%.

2. Розроблено і впроваджено в клінічну практику алгоритм оптимізації діагностичної тактики та хірургічної профрілактики можливих венозних тромбоемболічних ускладнень у хворих на рак ендометрія з урахуванням стану активності системи гемостазу та антропометричних даних і вмотивовано надано дієві практичні рекомендації.
\end{abstract}

КЛЮчОВІ СЛОВА: профілактика тромбоемболічних ускладнень; індивідуальний підхід; пангістеректомія; рак ендометрія.

Злоякісні пухлини репродуктивної системи жінок посідають значне місце в структурі онкологічної захворюваності. У 2017 р. відповідно до Національного канцер-реєстру стандартизований показник захворюваності на рак ендометрія (PE) в Україні склав 27,9 на 100 тис. жіночого населення і займає 2 місце після раку молочної залози серед питомої ваги 10 основних нозологічних форм злоякісних новоутворень (3Н), не включаючи немеланомні 3Н шкіри, і 2-3 місце (9,3-13,0 \%) за питомою вагою смертності в статево-віковій групі серед питомої ваги 10 основних нозологічних фрорм ЗН без немеланомних ЗН шкіри [1].

Онкологічні захворювання - один із найбільш значущих фракторів ризику тромботичних ускладнень (ТУ), за даними літератури в 5-35 \% хворих із злоякісними новоутвореннями спостерігають венозні тромбоемболічні ускладнення (ВТЕУ).

(с) І. В. Жулкевич, Б. Д. Кривокульський, 2018
ВТЕУ $€$ однією із основних причин смерті в онкології. Тромбоз глибоких вен (ТГВ) нижніх кінцівок і малого таза в 80 \% випадків клінічно не проявляється. Патогенетичні механізми, що зумовлюють ТУ в хворих на рак ендометрія, включають комплекс взаємодії пухлини і системи гемостазу.

Поширеність венозних тромбоемболій в пацієнтів із онкогінекологічною патологією підтверджена різними дослідниками [12, 13]. Висока частота тромбоемболічних ускладнень (ТЕУ) у пацієнтів із новоутвореннями жіночих статевих органів, виникнення пізніх і рецидивуючих тромбоемболій зумовлює необхідність оптимізації антитромботичної терапії, превентивної діагностики [14]. Тромбоз глибоких вен нижніх кінцівок і тромбоемболія легеневої артерії (ТЕЛА) $€$ найнебезпечнішими ускладненнями в онкології, а наявність раку - основний ризик венозного тромбозу. 
Проблема профрілактики тромботичних ускладнень залишається досить актуальною в онкології. Згідно з джерелами світової літератури [2, 4], у 15-35 \% онкологічних хворих спостерігають ТУ на хірургічному етапі лікування. Зокрема у пацієнтів із злоякісними новоутвореннями репродуктивних органів ТУ клінічно проявляються тільки у половині випадків, істинна частота значно вища. При автопсії було доведено, що серед хворих, які померли від раку, частота тромбозу досягала $50 \%$ [8]. Онкологічні хворі, в яких розвивались ТУ, мають у 2-3 рази вищу смертність, ніж хворі без ТУ $[5,11]$. Венозні тромбоемболії (ВТЕ) $€$ однією з найчастіших [15], а за деякими даними [9], - другою за частотою причиною смерті пацієнтів онкологічного профрілю.

Мета дослідження: підвищити ефективність хірургічного лікування хворих на рак ендометрія шляхом оптимізації діагностичної тактики та хірургічної профілактики тромботичних ускладнень у ранній післяопераційний період.

Матеріали і методи. Обстежено 3 групи жінок: I - група 30 соматично здорових жінок (донори), що слугувала контролем для вивчення показників системи гемостазу; II - контрольна група (група порівняння) - ретроспективно проаналізовано 120 карт стаціонарних хворих на РЕ, яким виконано пангістеректомію в онкологічному диспансері в період 2010-2013 рр.; III - основна група обстежених жінок, хворих на РЕ, яким виконували хірургічне втручання (пангістеректомію) - 147 хворих, які перебували на хірургічному лікуванні 3 приводу РЕ в 2014-2017 рр. у гінекологічному відділенні Тернопільського обласного клінічного онкологічного диспансеру та кафедри онкології, променевої діагностики і терапії та радіаційної медицини ДВНЗ «Тернопільський державний медичний університет імені І. Я. Горбачевського МОЗ України».

Діагноз раку ендометрія, показання та протипоказання до оперативного лікування встановлювали відповідно до міжнародних стандартів (ESMO-ESGO-ESTRO Consensus Conferenceon Endometrial Cancer: diagnosis, treatment and follow-up.// European Society for Medical Oncology (ESMO), European Society for Radiotherapy \& Oncology (ESTRO) and European Society of Gynaecological Oncology (ESGO) consensus conference on endometrial cancer was held on 1113 December 2014 in Milan, Italy), стандартів діагностики та лікування - Національного інституту раку, локального протоколу медичної допомоги та клінічного маршруту хворих на рак ендометрію Національного інституту раку та Тернопільського обласного клінічного онкологічного диспансеру.

У процесі клінічного доопераційного обстеження враховували дані анамнезу (в тому числі й тромботичного), визначали стадію захворювання, гістологічну характеристику видаленого новоутворення, обсяг і час операції, особливості перебігу післяопераційного періоду.

У всіх обстежуваних хворих на PE визначали основні клініко-антропометричні показники: вік, зріст, масу тіла, абсолютну поверхню тіла за Benerjec i Sen, відносну поверхню тіла, відносну масу тіла, біомас-індекс за А. Keysetal, індекс маси тіла (IMT), площу поверхні тіла.

Стан системи згортання крові хворих аналізували: до операції, під час операції і на 1, 5, 8 доби післяопераційного періоду. Показники гемостазу аналізували за параметрами, які відображають стан основних ланок системи гемостазу: прокоагулянтну, антикоагулянтну, фрібринолітичну з маркерами внутрішньосудинного згортання крові, а саме визначали: протромбіновий час (ПЧ) та протромбіновий індекс (ПІ), активований частковий тромбопластиновий час (АЧТЧ), фрібриноген (ФГ), D-димер, антитромбін III (AT-III), протеїн C, які здійснювали на коагулометрах Steellax M200, TS 4000 з використанням тест-систем: Техпластинтест, Steellax, Roche.

Хворим на PE проводили загальноклінічні та динамічні дослідження системи гемостазу в доопераційний і ранній післяопераційний періоди, що порівнювали 3 даними, отриманими в контрольній групі та групі соматично здорових жінок. Кожній пацієнтці визначали ризик ВТЕУ за шкалою J. Caprini [7], яка включає оцінку фракторів ризику, виражену в балах, і дозволяє провести стратифікацію обстежених нами жінок на групи низького, помірного, високого і вкрай високого ризику виникнення ВТЕУ.

У кожної пацієнтки визначали індекс коморбідної патології Charlson, який являє собою бальну систему оцінки віку і наявності супутніх захворювань та прогнозує виживання хворих [6].

При доопераційному обстеженні жінок, хворих на PE, достовірний діагноз тромбозу вен встановлювали на основі аналізу результатів інструментальних методів дослідження: ультразвукового дуплексного сканування та еластографії судин нижніх кінцівок та малого таза [10]. УЗД-дослідження та еластографрію проводили на УЗД-сканері експертного класу SIMENS ACUSONS 2000.

Особливістю проведеного дослідження було поєднання двох дизайнів наукових досліджень, ретроспективного, в якому ми дослідили 120 карт стаціонарних хворих (III група - група порівняння) 3 метою встановлення частоти ВТЕУ, та проспективного контрольованого дослідження, в якому ми обстежили дві групи жінок. 3 метою виявлення порушень в системі гемостазу в обстежених хворих досліджено 30 соматично здорових жінокдонорів, що слугувала контролем для вивчення показників системи гемостазу (І група), та 147 жінок, хворих на PE, яким проведено оперативне 
лікування. Особливістю проведеної проспективної частини нашого дослідження $€$ динамічний лабораторний контроль стану системи гемостазу в II групі хворих на доопераційному етапі, під час операції та ранньому післяопераційному періоді (1, 5, 8 доба).

Статистичний аналіз даних матеріалів передбачав такі статистичні методи: робастний критерій Левена-Форсайта як критерій спростування нульової гіпотези; точний метод Фішера і критерій хі-квадрат для аналізу альтернативних ознак і даних, визначених на дискретних шкалах вимірювання; кореляційний аналіз за критерієм Пірсона; математичне моделювання - множинна регресія з оцінкою за критерієм Фішера.

Результати дослідження та їх обговорення. На першому етапі нашого дослідження ми проаналізували основні антропометричні характеристики обстежених жінок і ризик виникнення ВТЕУ за шкалою J. Caprini (табл. 1).

Таблиця 1. Характеристика обстежених жінок

\begin{tabular}{|c|c|c|c|}
\hline Показники & $\begin{array}{c}\text { Основна група } \\
(n=147)\end{array}$ & $\begin{array}{c}\text { Група порівняння } \\
(\mathrm{n}=120)\end{array}$ & $\begin{array}{c}\text { Донори } \\
(\mathrm{n}=30)\end{array}$ \\
\hline Середній вік (роки) & $59,22 \pm 0,78^{*}$ & $58,93 \pm 0,72^{*}$ & $32,23 \pm 0,50$ \\
\hline Середній зріст (см) & $160,22 \pm 0,60$ & $160,81 \pm 0,64$ & $158,87 \pm 0,81$ \\
\hline Середня маса (кг) & $81,77 \pm 1,42^{\star}$ & $84,28 \pm 1,70 *$ & $53,10 \pm 0,80$ \\
\hline IMT (кг/M²) & $31,88 \pm 0,54^{*}$ & $32,54 \pm 0,61^{*}$ & $21,04 \pm 0,28$ \\
\hline Бали ризику ВТЕУ за шкалою Caprini & $6,26 \pm 0,08^{*}$ & $4,66 \pm 0,06^{*}$ & $0,27 \pm 0,08$ \\
\hline ППТ (M²) & $1,90 \pm 0,02^{*}$ & $1,93 \pm 0,02^{*}$ & $1,53 \pm 0,02$ \\
\hline
\end{tabular}

Примітка. * - достовірна різниця відносно показника групи здорових осіб (донори) за критерієм Брауна-Форсайта $(0,001<p<0,05)$.

В основній групі обстежених, а також і в групі порівняння виявлено зростання ризику виникнення ВТЕУ за шкалою J. Caprini порівняно з групою здорових осіб, що вказувало на високий і вкрай високий ризик виникнення ВТЕУ на операційному етапі лікування.

Проаналізувавши індекс коморбідності за Charlson у основній групі хворих на РЕ встановлено, що 2 бали мала одна пацієнтка (0,68\%), 3 бали - 19 жінок (12,92\%), 4 бали - 45 пацієнток (30,62 \%), 5 балів - 43 жінки (29,25\%), 6 балів 24 пацієнтки (16,33\%), 7 балів - 6 жінок (4,08 \%), 8 балів - одна пацієнтка (0,68 \%), 9 балів - 5 жінок (3,40\%), 10 балів - 3 жінки (2,04\%). У групі порівняння за індексом коморбідності Charlson 3 бали мали 7 жінок (5,83 \%), 4 бали - 36 пацієнток (30,0 \%), 5 балів - 53 жінки (44,17\%), 6 балів 14 жінок (11,66 \%), 7 балів - 5 пацієнток (4,16\%), 8 балів - 5 жінок (4,16\%).

Динамічне вивчення основних гемостазіологічних показників в основній групі та групі порівняння у доопераційний, інтраопераційний і ранній післяопераційний періоди у зіставленні з групою здорових жінок наведено в таблиці 2.

Гіперкоагуляція у хворих на РE з ознаками хронічного внутрішньосудинного згортання крові проявлялась достовірним $(0,001<p<0,05)$ зниженням протромбінового індексу та скороченням ТЧ і АЧТЧ $(0,001<p<0,05)$ з одночасним підвищенням рівня ПЧ, ФГ, D-димеру $(0,001<p<0,05)$. Ознаки гіперкоагуляції зростали під час операції та на 1-5 доби післяопераційного періоду і поступово знижувались до доопераційних значень, за винятком D-димеру, пік якого спостерігали на 8 добу післяопераційного періоду.

Порівнюючи дані показників гемостазу обстежених нами хворих на РЕ жінок до операції з групою порівняння та здоровими особами, достовірно $(0,001<p<0,05)$ відзначено зниження рівнів протромбіну, МНВ, АЧТЧ, АТ-ІІІ, протеїну С, тромбінового часу $-4,29 \%(0,001<p<0,05)$ та підвищений рівень протромбінового часу на 3,97 \%; фрібриногену - на 12,04 \% (0,001<p<0,05), D-димеру - на $26,58 \%(0,001<p<0,05)$, що свідчить про ознаки гіперкоагуляції.

Оцінюючи стан системи гемостазу під час операції, ознаки гіперкоагуляції спостерігали за наступними показниками: ПІ знизився на 1,23 \% $(0,001<p<0,05)$, рівень D-димеру збільшився на $63,29 \%(0,001<p<0,05)$, зниження показників: ФГ на $27,80 \%(0,001<p<0,05)$, АТ-III, ПС - на 3,26\% $(0,001<p<0,05)$ порівняно із значеннями до операції. Зниження АТ-ІІІ свідчило про виснаження системи інактивації тромбіну та плазмін-калекреїнової системи регуляції агрегатного стану крові.

Окремо проаналізовано динаміку змін рівня D-димеру в основній групі хворих із II і III стадією PE на доопераційному, інтраопераційному та ранньому післяопераційному періодах (рис. 1).

Динамічна оцінка рівня D-димеру в жінок, хворих на РE, при III стадії захворювання була достовірно $(p<0,05)$ вищою на доопераційному, інтраопераційному етапах нашого дослідження, проте в жінок, хворих на РЕ, при II стадії спостерігали тривале збільшення цього показника на 1-8 добу післяопераційного періоду. 
Таблиця 2. Показники гемостазу в основній групі хворих на РЕ в доопераційний, інтраопераційний і ранній післяопераційний періоди порівняно із групою порівняння та здоровими особами в доопераційний період

\begin{tabular}{|c|c|c|c|c|c|c|c|}
\hline \multirow{4}{*}{ Показник } & \multirow{4}{*}{$\begin{array}{c}\text { Здорові } \\
\text { особи }\end{array}$} & \multicolumn{6}{|c|}{ Хворі на рак ендометрія } \\
\hline & & \multirow{3}{*}{$\begin{array}{c}\text { група } \\
\text { порівняння } \\
\text { (до } \\
\text { операції) }\end{array}$} & \multicolumn{5}{|c|}{ основна група хворих } \\
\hline & & & \multirow{2}{*}{ до операції } & \multirow{2}{*}{$\begin{array}{c}\text { під час } \\
\text { операції }\end{array}$} & \multicolumn{3}{|c|}{ післяопераційний період } \\
\hline & & & & & 1 доба & 5 доба & 8 доба \\
\hline $\mathrm{n}$ & 30 & 120 & 147 & 147 & 147 & 147 & 147 \\
\hline П। (\%) & $89,85 \pm 1,02$ & $88,83 \pm 0,75$ & $89,46 \pm 0,76^{\alpha}$ & $87,83 \pm 0,56^{\circ}$ & $83,59 \pm 0,66^{\star}$ & $86,54 \pm 0,75^{\Delta}$ & $89,46 \pm 0,55$ \\
\hline ПЧ (c) & $14,52 \pm 0,17$ & $15,09 \pm 0,10$ & $15,12 \pm 0,09^{\alpha}$ & $15,67 \pm 0,74^{\circ}$ & $16,5 \pm 0,09^{\star}$ & $15,99 \pm 0,12^{\Delta}$ & $15,40 \pm 0,09^{+}$ \\
\hline МНВ (ум. од.) & $1,14 \pm 0,01$ & $1,11 \pm 0,01$ & $1,11 \pm 0,01^{\alpha}$ & $1,16 \pm 0,01^{\circ}$ & $1,23 \pm 0,01^{*}$ & $1,19 \pm 0,01^{\Delta}$ & $1,14 \pm 0,01$ \\
\hline ТЧ (\%) & $12,34 \pm 0,20$ & $12,10 \pm 0,09$ & $11,81 \pm 0,07^{\alpha}$ & $12,36 \pm 0,06^{\circ}$ & $13,4 \pm 0,11^{*}$ & $13,05 \pm 0,10^{\Delta}$ & $\overline{12,48 \pm 0,09^{+}}$ \\
\hline АЧТЧ (c) & $28,63 \pm 0,47$ & $28,51 \pm 0,21$ & $28,05 \pm 0,14^{\alpha}$ & $29,54 \pm 0,19^{\circ}$ & $32,82 \pm 0,21^{*}$ & $32,38 \pm 0,20^{\Delta}$ & $30,37 \pm 0,19^{+}$ \\
\hline ФГ (г/л) & $2,74 \pm 0,12$ & $3,03 \pm 0,06$ & $3,13 \pm 0,08^{\alpha}$ & $2,26 \pm 0,05^{\circ}$ & $2,89 \pm 0,07^{\star}$ & $3,01 \pm 0,06$ & $2,95 \pm 0,05^{+}$ \\
\hline AT-III (\%) & $93,83 \pm 1,26$ & - & $91,37 \pm 0,57^{\alpha}$ & $90,97 \pm 0,57^{\circ}$ & $98,07 \pm 0,97^{\star}$ & $102,9 \pm 1,01$ & $99,9 \pm 0,90$ \\
\hline$\Pi$ ПС (\%) & $94,01 \pm 0,51$ & - & $92,03 \pm 0,41^{\alpha}$ & $88,25 \pm 0,61^{\circ}$ & $97,12 \pm 0,51^{*}$ & $104,1 \pm 1,01$ & $102,0 \pm 0,91$ \\
\hline $\begin{array}{l}\text { D-димер } \\
\text { (мг/мл) }\end{array}$ & $0,21 \pm 0,01$ & - & $0,79 \pm 0,06^{\alpha}$ & $1,29 \pm 0,10^{\circ}$ & $1,20 \pm 0,05$ & $1,48 \pm 0,07$ & $1,64 \pm 0,08^{+}$ \\
\hline
\end{tabular}

Примітки. ${ }^{\alpha}$ - достовірна різниця стосовно показника до операції відносно показників у контрольній групі за критерієм Брауна-Форсайта $(0,001<p<0,05) ;{ }^{\circ}$ - достовірна різниця відносно показника дооперації за критерієм Брауна-Форсайта $(0,001<p<0,05) ;$ * - достовірна різниця відносно показника під час операції за критерієм Брауна-Форсайта $(0,001<p<0,05) ;{ }^{\Delta}$ - достовірна різниця відносно показника 1 доби післяопераційного періоду за критерієм Брауна-Форсайта $(0,001<p<0,05) ;{ }^{+}$- достовірна різниця відносно показника 5 доби післяопераційного періоду за критерієм Брауна-Форсайта $(0,001<\mathrm{p}<0,05)$.

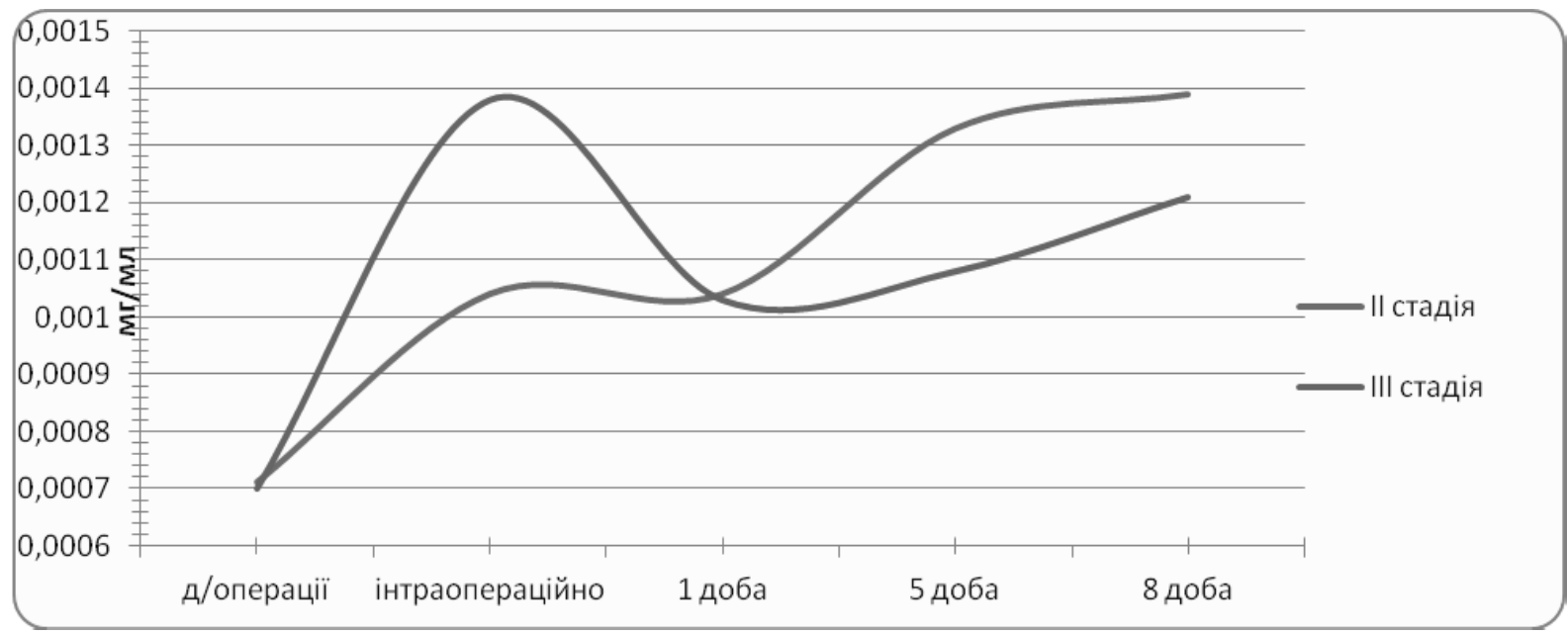

Puc. 1. Динаміка змін рівня D-димеру в основній групі хворих із II і III стадією раку ендометрія.

Нами встановлено статистично достовірну різницю $(p<0,05)$ показників системи гемостазу в хворих із різними антропометричними показниками, які підтверджено й кореляційними зв'язками. Так констатовано наявність статистично достовірного $(p<0,05)$ позитивного взаємозв'язку між тромбозом вен малого таза та масою тіла, IMT, показниками шкали Caprini, ППТ, ТЧ, АЧТЧ, фрібриногеном, рівнем D-димеру. Достовірний $(p<0,05)$ негативний взаємозв'язок встановлено між тромбозом вен малого таза та співвідношенням рівня ПС до рівня D-димеру; ТЧ до D-димеру; AT-III до D-димеру.
На основі виявлених кореляційних зв'язків створено математичну модель (рівняння множинної регресії) прогнозу наявності (відсутності) тромбів у венах малого таза [3]. В її основу покладено показники з високим рівнем кореляції до наявності тромбів (виявлених у ході оперативного втручання) у венах малого таза: антропометричні дані; бальну оцінку ВТЕУ за шкалою Caprini та рівень D-димеру, що дозволило нам створити алгоритм оптимізації діагностичної та хірургічної тактики (рис. 2), який полягає у використанні на доопераційному етапі визначення рівня D-димеру як прогностичного маркера тромбозу 


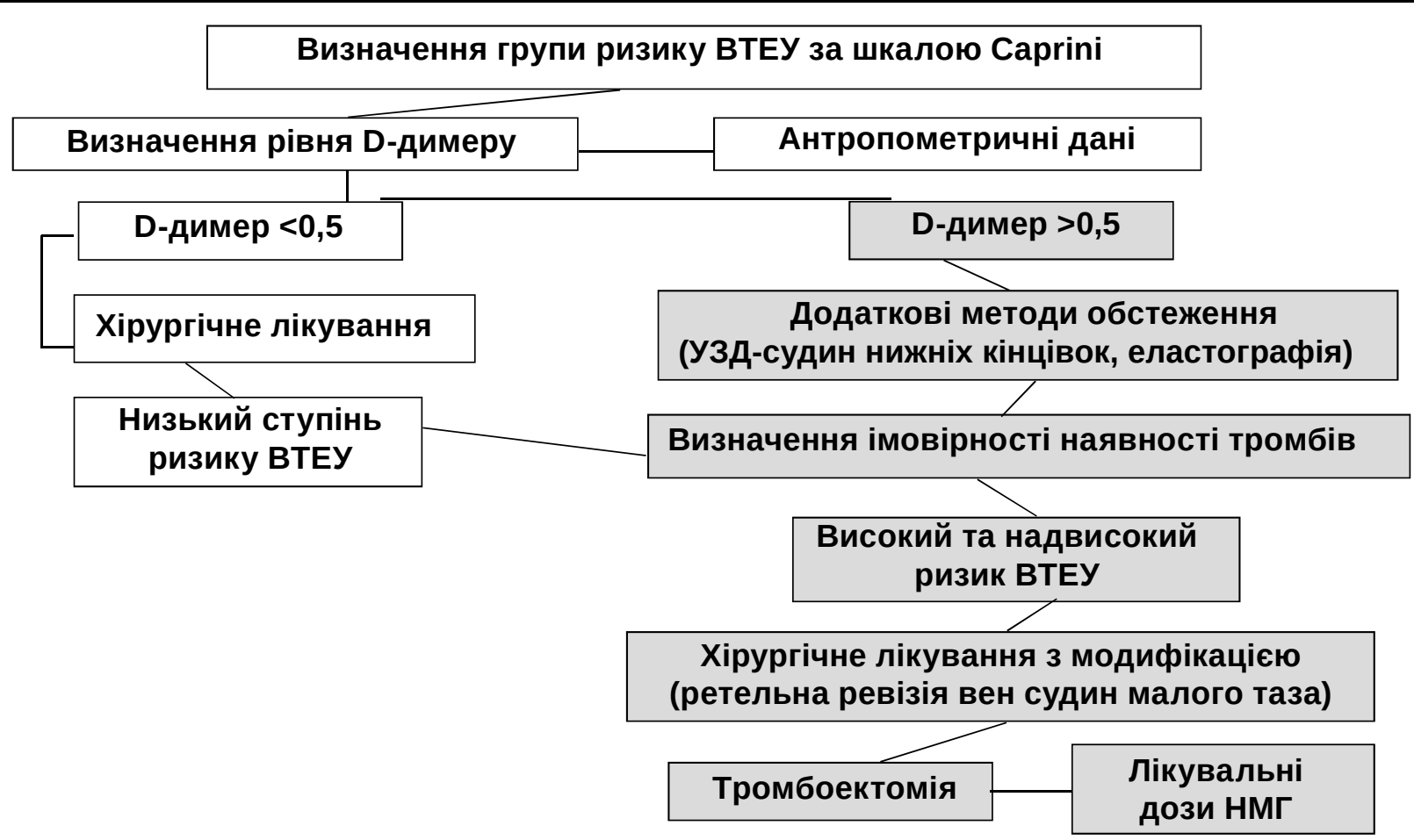

Puc. 2. Алгоритм оптимізації діагностичної та хірургічної тактики у хворих на рак ендометрія з урахуванням ризику можливих венозних тромбоемболічних ускладнень.

та антропометричних даних конкретної хворої на PE для передбачення ймовірності тромбозу в венах малого таза.

Залежно від отриманих даних на діагностичному етапі операції передбачені зміни в оперативній тактиці (ретельна ревізія вен малого таза, виконання тромбоектомії, за потреби, і переведення на лікувальні дози НМГ у післяопераційний період).

Аналізуючи частоту післяопераційних ТУ і летальності в ранній післяопераційний період в основній групі та групі порівняння можна вмотивовано стверджувати, що внаслідок використання алгоритму оптимізації діагностичної та хірургічної тактики у хворих на РЕ з урахуванням ризику можливих ВТЕУ досягнуто зниження смертності в ранній післяопераційний період у хворих на рак ендометрія від ТЕЛА з 4,17 до 0 \% і післяопераційних тромботичних ускладнень - 3 11,67 до 1,36 \% у ранній післяопераційний період (рис. 3).

Результати роботи впроваджено у клінічну практику Тернопільського, Хмельницького, Ужгородського обласних онкологічних диспансерів, ДУ «Інститут медичної радіології ім. С. П. Григор'єва Національної академії медичних наук України».

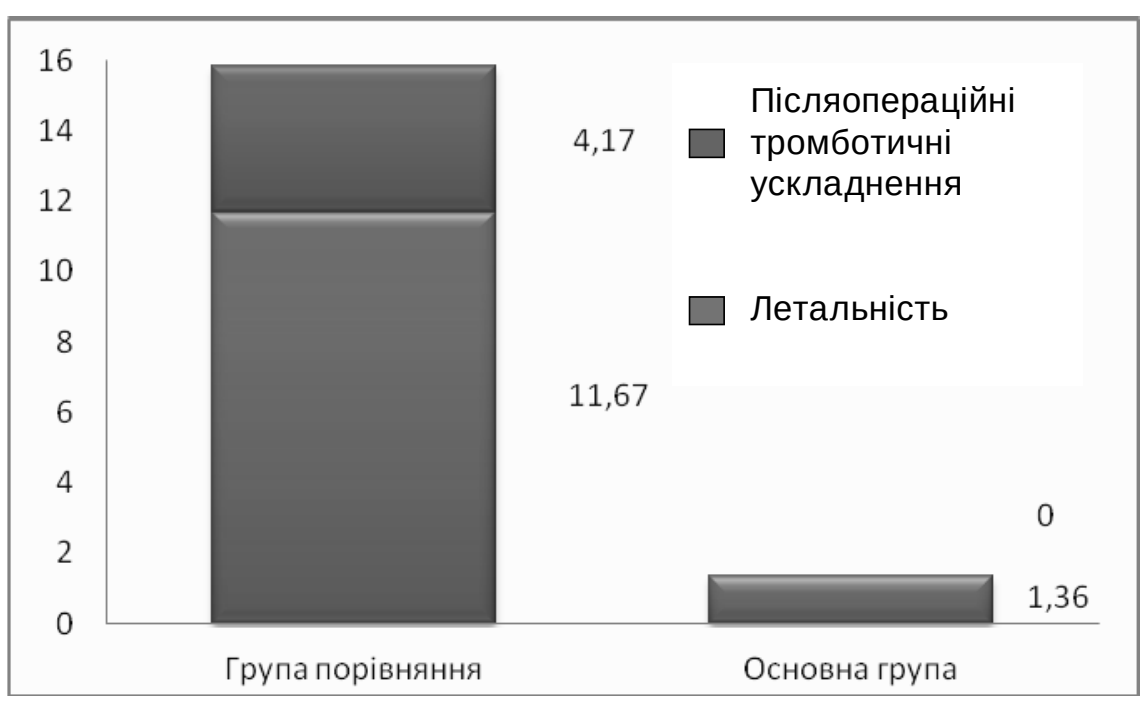

Puc. 3. Частота післяопераційних тромботичних ускладнень і летальності (\%) в основній і групі порівняння в ранній післяопераційний період. 


\section{Висновки}

1. Досягнуто зниження смертності в ранній післяопераційний період у хворих на рак ендометрія від ТЕЛА з 4,17 до 0 \% і післяопераційних тромботичних ускладнень - 3 11,67 до 1,36 \% у ранній післяопераційний період.

2. Розроблено і впроваджено в клінічну практику алгоритм оптимізації діагностичної тактики та хірургічної профрілактики можливих ВТЕУ в хворих на рак ендометрія з урахуванням стану активності системи гемостазу (за рівнем D-димеру) та антропометричних даних і вмотивовано дієві практичні рекомендації щодо переведення хворих на рак ендометрія з профрілактичних на лікувальні дози низькомолекулярних гепаринів у ранній післяопераційний період.

Перспективи подальших досліджень полягають у вивченні стану системи гемостазу в прооперованих хворих на рак ендометрія в пізній післяопераційний період на фроні адекватної антитромботичної терапії.

\section{Список літератури}

1. Бюлетень Національного канцер-реєстру № 19 - «Рак в Україні, 2016-2017» / за ред. О. О. Колеснік. - 2018. $134 \mathrm{c}$.

2. Варданян А. В. Послеоперационные венозные тромбоэмболические осложнения - реальная опасность и современные методы профилактики / А. В. Варданян // Ангиология и сосудистая хирургия. - 2008. - Т. 4, № 1. C. 67-72.

3. Кривокульський Б. Д. Ризик адаптовані підходи до профрілактики тромботичних ускладнень при гістеректомії / Б. Д. Кривокульський, І. В. Жулкевич // Шпитальна хірургія. Журнал імені Л. Я. Ковальчука. - 2018. - № 2 (82). С. 78-83.

4. Синдром Руссо : современный взгляд на проблему / А. В. Воробьев, А. Д. Макацария, А. М. Чабров, А. А. Савченко // Журнал акушерства и женских болезней. - 2015. - № 4. - С. 85-94.

5. Шилова А. Н. Методы медикаментозной профилактики и лечения тромбозов у онкологических больных, их влияние на рост и метастазирование опухолей, на выживаемость больных (обзор литературы) / А. Н. Шилова // Сибирский онкологический журнал. - 2012. - № 2 (50). - С. 79-83.

6. Arcelus J. I. Venous thromboprophylaxis duration and adherence to international guidelines in patients undergoing major orthopaedic surgery: Results of the international, longitudinal, observational DEIMOS registry / J. I. Arcelus // Thromb. Res. - 2013. - Vol. 131, Issue 6. - P. 240-246.

7. Caprini J. A. Thrombotic risk assessment: A hybrid approach. - 2013. - Mode access : https://www.venousdisease.com /Publications/ JACaprini-HybridApproach3-10-05.pdf.

8. Kakkar A. K. Compliance with recommended prophylxis for venous thromboembolism: improving the use and rate of uptake of clinical practice guidelines / A. K. Kakkar, B. L. Davidson, S. K. Haas // J. Thromb. Haemost. - 2004. Vol. 2. - P. 221-227.

9. Donati M. B. Cancer and thrombosis / M. B. Donati // Haemostasis. - 1994. - Vol. 24. - P. 128-131.

10. Elastography: from theory to clinical applications : Summer Bioengineering Conference (Sonesta Beach Resort, June 25-29, 2003) / E. E. Konofagou, J. Ophir, T. A. Krouskop, B. S. Garra. - Key Biscayne, Florida, 2003. Mode access : http:// www.tulane.edu/ sbc2003/pdfdocs/0367.

11. Kobayashi T. Prophylaxis and treatment of venous thromboembolism based on Japanese clinical guides / T. Kobayashi // Rinsho Ketsueki. - 2017. - Vol. 58, No. 7. - P. 875-882.

12. Mandala $M$. Management of venous thromboembolism in cancer patients: ESMO clinical recommendations / M. Mandala, A. Falanga, F. Roila // Ann. Oncol. - 2009. - Vol. 20 (Suppl. 4). - P. 182-184.

13. Risk of Venous Thromboembolism after laparoscopic surgery for gynecologic malignancy / $\mathrm{H}$. Mahdi, Q. Aljebori, D. Lockart, L. Moulton // J. Minim. Invasive Gynecol. - 2016. - Vol. 23, No. 7. - P. 1057-1062.

14. The association of active cancer with venous thromboembolism location: A population-based study / A. J. Tafur, H. Kalsi, W. E. Wysokinski [et al.] // Mayo Clin. Proc. - 2011. - Vol. 86, No. 1. - P. 25-30.

15. The clinical course of venous thromboembolism may differ according to cancer site / I. Mahé, J. Chidiac, L. Bertoletti [et al.] // Am. J. Med. - 2017. - Vol. 130, No. 3. - P. 337-347.

\section{References}

1. Kolesnik, O.O. (Ed.). (2018). Byuleten Natsionalnoho kantser-reiestru No. 19 - "Rak v Ukraini, 2016-2017" [Bulletin of the National Chancery Register No. 19 - "Cancer in Ukraine, 2016-2017"] [in Ukrainian].

2. Vardanyan, A.V. (2008). Posleoperatsionnyye venoznyye tromboembolicheskiye oslozhneniya - realnaya opasnost i sovremennyye metody profilaktiki [Postoperative venous thromboembolism complications - real danger and modern methods of prophylaxis]. Angiologiya i sosudistaya khirurgiya - Angiology and Vascular Surgery, 4, 1, 67-72 [in Russian]. 3. Kryvokulskyi, B.D., \& Zhulkevych, I.V. (2018). Ryzyk adaptovani pidkhody do profilaktyky trombotychnykh uskladnen pry histerektomii [Risk adapted approaches to the prevention of thrombotic complications with hysterectomy]. Shpytalna khirurhiia. Zhurnal imeni L.Ya. Kovalchuka - Hospital Surgery. Journal named after L. Ya. Kovalchuk, 2 (82), 78-83 [in Ukrainian].

4. Vorobyev, A.V., Makatsariya, A.D., Chabrov, A.M., \& Savchenko, A.A. (2015). Sindrom Russo: sovremennyy vzglyad na problemu [Rousseau syndrome: a modern view on the problem]. Zhurnal akusherstva i zhenskikh bolezney - Journal of Obstetrics and Women's Diseases, 4, 85-94 [in Russian]. 
5. Shilova, A.N. (2012). Metody medikamentoznoy profilaktiki i lecheniya trombozov u onkologicheskikh bolnykh, ikh vliyaniye na rost i metastazirovaniye opukholey, na vyzhivayemost bolnykh (obzor literatury) [Methods of drug prevention and treatment of thrombosis in cancer patients, their effect on the growth and metastasis of tumors, on the survival of patients (literature review)]. Sibirskiy onkologicheskiy zhurnal - Siberian Oncological Journal, 2 (50), 79-83 [in Russian]. 6. Arcelus, J.I. (2013). Venous thromboprophylaxis duration and adherence to international guidelines in patients undergoing major orthopaedic surgery: Results of the international, longitudinal, observational DEIMOS registry. Thromb. Res., 131, 6, 240-246.

7. Caprini, J.A. (2013). Thrombotic risk assessment: A hybrid approach. Retrieved from: https://www.venousdisease.com / Publications/ JACaprini-HybridApproach3-10-05.pdf.

8. Kakkar, A.K., Davidson, B.L., \& Haas, S.K. (2004). Compliance with recommended prophylxis for venous thromboembolism: improving the use and rate of uptake of clinical practice guidelines. J. Thromb. Haemost, 2, 221-227. 9. Donati, M.B. (1994). Cancer and thrombosis. Haemostasis, 24, 128-131.

10. Konofagou, E.E., Ophir, J., Krouskop, T.A., \& Garra, B.S. (2003). Elastography: from theory to clinical applications: Summer Bioengineering Conference (Sonesta Beach Resort, June 25-29, 2003). Key Biscayne, Florida. Retrived from: http://www.tulane.edu/ sbc2003/pdfdocs/0367.

11. Kobayashi, T. (2017). Prophylaxis and treatment of venous thromboembolism based on Japanese clinical guides. Rinsho Ketsueki, 58, 7, 875-882.

12. Mandala, M., Falanga, A., \& Roila, F. (2009). Management of venous thromboembolism in cancer patients: ESMO clinical recommendations. Ann. Oncol, 20, 4, 182-184.

13. Mahdi, H., Aljebori, Q., Lockart, D., \& MoultonRisk, L. (2016). Of venous thromboembolism after laparoscopic surgery for gynecologic malignancy. J. Minim. Invasive Gynecol, 23, 7, 1057-1062.

14. Tafur, A.J., Kalsi, H., Wysokinski, W.E., McBane, R.D., Ashrani, A.A., Marks, R.S., .. \& Heit, J.A. (2011). The association of active cancer with venous thromboembolism location: A population-based study. Mayo Clin. Proc., 86, 1, 25-30.

15. Mahé, I., Chidiac, J., Bertoletti, L., Font, C., Trujillo-Santos, J., Peris, M., ... \& Monreal, M. (2017). The clinical course of venous thromboembolism may differ according to cancer site. Am. J. Med., 130, 3, 337-347.

\section{ПЕРСОНАЛИЗАЦИЯ В ОНКОЛОГИИ: ИНДИВИДУАЛЬНЫЙ ПОДХОД К ПРОФИЛАКТИКЕ ТРОМБОЭМБОЛИЧЕСКИХ ОСЛОЖНЕНИЙ ПРИ ПАНГИСТЕРЭКТОМИИ}

И. В. Жулкевич ${ }^{1}$, Б. Д. Кривокульский

${ }^{1}$ ГВУЗ «Тернопольский государственный медицинский университет имени И. Я. Горбачевского МЗ Украины», г. Тернополь, Украина

${ }^{2}$ Тернопольский областной клинический онкологический диспансер, г. Тернополь, Украина

Цель: повысить эффективность хирургического лечения больных раком эндометрия путем оптимизации диагностической тактики и хирургической профилактики тромботических осложнений в раннем послеоперационном периоде.

Материалы и методы. Обследовано 3 группы женщин: I - группа 30 соматически здоровых женщин; II - контрольная группа (группа сравнения) - ретроспективно проанализированы 120 карт стационарных больных раком эндометрия, которым выполнена пангистерэктомия в период 2010-2013 гг.; III - основная группа женщин, больных раком эндометрия, которым выполнялось хирургическое вмешательство (пангистерэктомия) - 147 больных, находившихся на хирургическом лечении в 2014-2017 гг.

Результаты. На первом этапе нашего исследования проанализированы основные антропометрические характеристики обследованных женщин и риск тромботических осложнений по шкале J. Caprini. В основной группе обследованных и в группе сравнения рост риска возникновения тромбоэмболии по сравнению с группой здоровых лиц, что указывало на высокий и крайне высокий риск их возникновения на операционном этапе лечения.

Изучение гемостазиологических показателей в основной группе и группе сравнения в дооперационном, интраоперационном и раннем послеоперационном периоде выявило гиперкоагуляцию с признаками внутрисосудистого свертывания, что проявлялась достоверным снижением протромбинового индекса и сокращением ТВ и АЧТВ с одновременным повышением уровня ПЧ, ФГ, D-димера. Признаки гиперкоагуляции росли во время операции и на 1-5 сутки послеоперационного периода и постепенно снижались до дооперационных значений, за исключением D-димера, пик которого наблюдали на 8 сутки послеоперационного периода.

Созданы и внедрены в практику здравоохранения алгоритм оптимизации диагностической и хирургической профилактики тромбоэмболических осложнений у больных раком эндометрия с учетом риска их возникновения.

Выводы. 1. Достигнуто снижение смертности в раннем послеоперационном периоде у больных раком эндометрия от тромбоэмболии легочной артерии с 4,17 до 0 \% и послеоперационных тромботических осложнений - с 11,67 до 1,36 \%.

2. Разработаны и внедрены в клиническую практику алгоритм оптимизации диагностической тактики и хирургической профрилактики возможных венозных тромбоэмболических осложнений у больных раком эндометрия с учетом состояния активности системы гемостаза и антропометрических данных и мотивировано предоставлены действенные практические рекомендации. 
КЛЮЧЕВЫЕ СЛОВА: профилактика тромбоэмболических осложнений; индивидуальный подход; пангистерэктомия; рак эндометрия.

\author{
PERSONALIZATION IN ONCOLOGY: INDIVIDUAL APPROACH TO THE PREVENTION OF \\ THROMBOEMBOLIC COMPLICATIONS DURING HYSTERECTOMY \\ I. V. Zhulkevych ${ }^{1}$, B. D. Kryvokulsky² \\ ${ }^{1}$ I. Horbachevsky Ternopil State Medical University \\ ${ }^{2}$ Ternopil Regional Clinical Oncology Center
}

Purpose: to increase the efficiency of surgical treatment of patients with endometrial cancer by optimizing diagnostic tactics and surgical prophylaxis of thrombotic complications in the early postoperative period.

Materials and Methods. Three groups of women were examined: I - group of 30 somatic healthy women; II control group (comparison group) - 120 cards of patients with endometrial cancer was analyzed retrospectively, which was surgical treatment in the period of 2010-2013; III - is the main group of women with endometrial cancer who underwent surgical intervention (hysterectomy) - 147 patients who were on surgical treatment in 2014-2017.

Results. At the first stage of our study, the main anthropometric characteristics of the examined women and the risk VTE on the J. Caprini scale were analyzed. In the main group of patients and in the comparison group, there was an increased risk of developing thromboembolism compared with a group of healthy individuals, indicating a high and very high risk of their occurrence at the surgical stage of treatment.

The study of hemostatic parameters in the main group and the comparison group in the preoperative, intraoperative and early postoperative period revealed hypercoagulation with signs of intravascular coagulation, manifested by a significant decrease in the prothrombin index and reduction of PT and APTT, with simultaneous increase in the level of FG, and D-dimer. Signs of hypercoagulation increased during the operation and for 1-5 days after the postoperative period and gradually decreased to preoperative values, with the exception of the D-dimer, whose peak was observed at the $8^{\text {th }}$ day of postoperative period.

The algorithm of optimization of diagnostic and surgical prophylaxis of thromboembolism in patients with endometrial cancer, taking into account the risk of their occurrence, was created and implemented in the practice of health care.

Conclusions. 1 . The reduction in mortality in the early postoperative period in patients with endometrial cancer from PE was $4.17 \%$ to $0 \%$ and postoperative thrombotic complications - from $11.67 \%$ to $1.36 \%$.

2. The algorithm for optimization of diagnostic tactics and surgical prophylaxis of possible VTE in patients with endometrial cancer is developed and implemented in the clinical practice, taking into account the state of activity of the hemostasis system and anthropometric data and motivated practical recommendations provided.

KEY WORDS: prophylaxis of thromboembolic complications; individual approach; hysterectomy; endometrial cancer.

Рукопис надійшов до редакції 14.11.2018 p.

Відомості про авторів:

Жулкевич Ігор Валентинович - професор кафредри онкології, променевої діагностики і терапії та радіаційної медицини ДВНЗ «Тернопільський державний медичний університет імені І. Я. Горбачевського МОЗ України»; тел.: +38(067) 630-23-52.

Кривокульський Богдан Дмитрович - лікар-онколог Тернопільського обласного клінічного онкологічного диспансеру; тел.: +38(067) 354-35-55. 